\title{
Византинци и писана реч
}

\author{
Радивој Радић \\ Универзитет у Београду \\ Филозофски факултет - Одељење за историју, Београд \\ rradic@f.bg.ac.rs
}

\begin{abstract}
Сажетак
Византијска цивилизација била је цивилизација рукописа и рукописних књига (кодекса) за које су коришћени папирус, пергамент и папир. Како би могле да се дистрибуирају до читалаца и како би се сачувале од пропадања, рукописне књиге су преписиване у скрипторијумима у којима нису деловали само монаси, него и световни људи различитих занимања. Књиге су биле веома скупе, а библиотеке јавне, царске, патријаршијске, монашке и приватне са не тако великим фондом рукописа. Како се византијска цивилизација ближила своме заласку, почела је селидба грчких рукописа из Византије у латински свет западне Европе. На тај начин је велико наслеђе античке цивилизације сачувано и пренето у европске земље.
\end{abstract}

Кључне речи: Византија, рукописи, кодекси, скрипторијуми, речи, цивилизација, антика, западна Европа

„По природи бела, али нисам јаје, листови су бројни, ни ротквица нисам.

Мудре и свете речи у себи носим,

и мада редовно на трпези лежим, ником, разуме се, за храну не служим."

(Визаниичска заїонейка)

(решење: књиїа)

Некако у исто време када је срушено Византијско царство (1453), у другом делу Европе, у граду Мајнцу, Јохан Гутенберг је завршио са штампањем прве књиге - латинске Библије (1455). То је био један од највећих проналазака у повести људског рода и цивилизацијски скок који је умногоме променио историју света. На другој страни, то је значило да је Византија, империја која је управо потонула у мутне воде историје, била и остала искључиво цивилизација рукописа и рукописне књиге (кодекса).

\section{У свету речи}

„Речи, речи, речи!“, чувено место из драмског опуса Вилијама Шекспира (Хамлет, II, 2) на особен начин може отворити читав низ могућих сагледавања овог пространог и вишезначног феномена. Хомер је лаконски закључио да је речник један богат пашњак речи, док је Анатол Франс мисао слепог песника осавременио и нагласио да је речник читав један свет поређан по азбучном реду.

Византија је од античке Грчке као највеће благо наследила реч Лоїос у вишеструком значењу. У питању је свеобухватан и широк филозофски појам који су користили мислиоци стоицизма и Филон Александријски, а прихватили богослови раног хришћанства, поистоветивши 
Исуса Христа са Логосом / „У почетку беше Логос (Реч) и Логос беше у Бога, и Логос беше Бог" - Јеванђеље по Јовану, 1, 1/. ${ }^{1}$ То је један од суштинских појмова грчке и хеленистичке, а затим и јеврејске и хришћанске филозофије и теологије, чије је основно значење реч, говор, односно ум, разум, у ширем смислу оно што је у основи света и збивања у њему врховно начело, божанска стваралачка снага (Реч божја, Реч као медијум стварања света, Реч као носилац живота и светлости). ${ }^{2}$ Поједини истраживачи чак иду дотле да су склони веровању како би допринос античке грчке цивилизације био сасвим довољан само у томе што је свету у наслеђе оставила појам Лоїос.

Спуштена у раван овоземаљског и свакодневног, реч задобија ауру цивилизацијског достигнућа и представља најпотпунију и најтананију спону за споразумевање међу људима. Вештину у употреби речи и умећу убеђивања речима Ромеји (Византинци) углачали су до потпуног сјаја, а њихова дипломатија, каткад претерано препредена и безобзирна, немилосрдно их је користила као средство у преговорима са осталим народима и државама. Ромејско убеђење у властиту посебност и увереност Византинаца у неприкосновено право на универзалну власт над читавом хришћанском васељеном изнедрили су једну врсту „империјалне свести“ из које је проистицао надмен и разметљив став према свим осталим народима.

Теодор Метохит, византијски интелектуалац и опуномоћени емисар цара Андроника II Палеолога (1282-1328) у преговорима о склапању брака српског краља Милутина и принцезе Симониде (1298/1299), у свом "Посланичком слову“, поверљивом извештају који је упутио у Цариград са последњег од својих пет путовања у Србију, забележио је: „А то је нарочито тако са овим варварима и ограниченим људима који се речима лако не препуштају, посебно уза такве сплетке, интриге и пакости, утолико више што они мисле да се ми највештије користимо речима, вештије и од њих и од осталих и да њима владамо, убеђујемо, преокрећемо и преобраћамо све како бисмо желели". ${ }^{3}$

Ипак, употреба речи у оквирима византијске цивилизације потпуно се расцветала и досегла је свој апогеј у књижевности која је неоправдано дуго погрешно сматрана за уско епигонску, беживотну, декадентну, без унутрашње снаге, заробљену у скученим оквирима окошталих образаца. Рехабилитација Византије, а самим тим и њене књижевности, чини занимљиво поглавље у развоју европске историјске мисли и естетских стремљења у 19. и 20. столећу. Оштроумно је изречена оцена да се Византија није променила, али наш приступ њеној цивилизацији свакако јесте и несумњиво ће се мењати и у будућности. ${ }^{4}$

Хомерови епови су први пут забележени, у облику који углавном имају и данас, у 7. веку пре Христа. Премда је одређених промена било, од тих древних времена до данас грчки језик има непрекинуту традицију. Он није доживео прекид сличан оном који постоји између латинског и романских језика. Другим речима, старогрчки није стран језик данашњим Грцима у оној мери у којој је англосаксонски савременим Енглезима. Уз грчки, једини други језик који се може подичити сличном непрекинутошћу у традицији је кинески. ${ }^{5}$

Важна одлика грчког језика у византијско време (4-15. век) јесте диглосија, тј. постојање два језика, ученог и китњастог којим се писало, с једне, и народског, једноставнијег којим се говорило, с друге стране. Временом, они су се све више разликовали и одвајали један од другог. Учена принцеза Ана Комнина, кћи цара Алексија I (1081-1118) и вероватно најобразованија Византинка, наводи како је у детињству морала да учи тај архаични грчки језик, заправо

\footnotetext{
1 The Oxford Dictionary of Byzantium, II, ed. A. P. Kazhdan (New York; Oxford, 1991), 1246. (У даљем тексту ODB).

2 Енииклойеgија ирравославља, II (Београд: Савремена администрација, 2002), 1118

3 „Теодор Метохит“, обрадио И. Бурић, у Визаншиијски извори за исйорију нароgа Јуїославије, VI (Београд: Византолошки институт САНУ, 1986), 143. Уп. Р. Радић, „Ромеји се највештије користе речима (Цртица о византијском умећу убеђивања)“, у Визанииија и Србија: йламен и оgсјаји (Београд: Стубови културе, 2010), 36-45.

${ }^{4}$ Oksfordska istorija Vizantije, prir. S. Mango, prev. M. Miloradović, P. J. Marković (Beograd: Dereta, 2004), 7-8.

5 Р. Браунинг, Среgњовековни и савремени ірики језик, прев. ). Петровић, допуна библиграфије Д. Аничић (Лозница: Карпос, 2005$), 5$.
} 
атички дијалект грчког језика, чије се знање вештачки одржавало кроз читав средњи век. Њен необразовани савременик тешко да би могао да разуме Анино историјско дело које спада међу ремек-дела византијске књижевности. ${ }^{6}$ Додајмо да је феномен диглосије, постојања два језика, ученог и народног, био својствен како латинском свету западне Европе, тако и словенском свету. Када је у питању грчки језик, та је диглосија надживела средњи век и чак дочекала

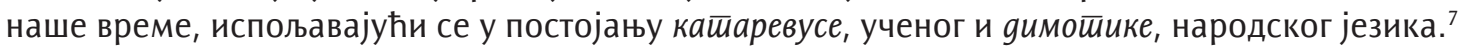

\section{Опрез са паганским наслеђем}

Као и древни Грци, и Византинци су се с дубоким поштовањем односили према знању. Цар Констанције (337-361) наглашавао је значај класичног образовања за своје поданике и на њега је гледао као на животну неопходност. Тако је остало и забележено у једном његовом закону који је касније, у првој половини 5. столећа, ушао у збирку важећих царских закона, тзв. Теодосијев кодекс (Codex Theodosianus), коју су 438. године уобличили правници цара Tеодосија II (408-450). У њему се каже да људи који владају „слободним вештинама“ заслужују свако поштовање. ${ }^{8}$

Науке које су се училе у римским школама назване су слободним (artes liberales) jep су се њима могли бавити слободни људи, док робовима то није било допуштено. Оне су биле темељ целокупног образовања (грчки: enkyklios paideia, енциклопедија). Већ је Марцијан Капела, филозоф 5. столећа, свео постојеће науке на седам (сеgам слобоgних вешйина). Предавале су се у два течаја: у нижем, тривијуму (trivium), биле су граматика, реторика и дијалектика, док су вишем ступњу, квадривијуму (quadrivium), припадале геометрија, аритметика, теорија музике и астрономија, при чему је филозофија схватана као синтеза свих наука. Основа средњовековног учења била је разрада тривијума и квадривијума која потиче од Флавија Касиодора (6. век). ${ }^{9}$

Григорије Назијански, један од највећих црквених отаца, познат и као Григорије Богослов, у посмртном слову свом пријатељу и колеги Василију Великом 379. године, назвао је античко образовање највишим благом, признавши да је то више од свега чиме су овладали хришћани. Још неки ранохришћански писци - Василије Велики, Сократ Схоластик и други - указивали су верујућима у Исуса Христа да је неопходно да добију световно образовање. Проучавање паганских аутора, посебно филозофа, који су умногоме надмашивали хришћанске писце, поткрепљивало је религијске догме и хришћанске мислиоце снабдевало материјалом и аргументима за оповргавање „грешака“ и „заблуда“ пагана и јеретика. ${ }^{10}$

Сократ Схоластик је наглашавао да су хришћани продужили да изучавају културу Хелена, мада је она била прожета духом политеизма страном једној монотеистичкој религији какво је било хришћанство. Да би објаснио ову парадоксалну појаву, Сократ Схоластик се ослонио на ауторитет јеванђеља која, према његовим речима, не садрже „ни одобравање ни негирање хеленске културе. “11 Можда нико није сликовитије објаснио однос хришћанских интелектуалаца према античком наслеђу него знаменити филозоф Михаило Псел у 11. веку. Он је најпре нагласио да су богослови паганско наслеђе делили на прихватљиво и неприхватљиво и, онда, прво узимали као храну, а друго испљувавали као да је реч о отрову. ${ }^{12}$

\footnotetext{
6 3. Г. Самодурова, „Школы и образование“, у Кульшерра Визанишии (вйорая йоловина VII-XII в.), II (Москва: Наука, 1989$), 366$. Браунинг, Среgњовековни и савремени ірики језик, 136-140.

8 3. Г. Самодурова, "Школы и образование“, у Кульшиура Визанйии (IV - йервая йоловина VII в.), I (Москва: Наука, 1984$), 478$.

${ }^{9}$ Dictionary of the Middle Ages, vol. X, ed. J. R. Strayer (New York: Scribner, 1988), 237-238; vol. XII (New York: Scribner, 1989), 205-207. (У даљем тексту DMA).

10 Культиура Визанйии, I, 478-479.

11 Нсто, 480.

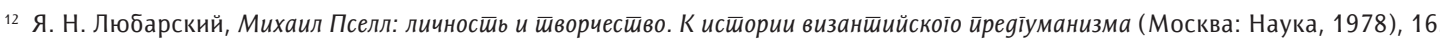


Уопште, важно је подвући чињеницу да је у том раном периоду хришћанство било интелектуално инфериорно у односу на паганство. Ако се, на пример, упореде Платон и Аристотел са Евсевијем из Кесарије или Северијаном из Гавале, нема сумње да је предност на страни ових првих! Тога су били свесни и сами средњовековни писци. Тако је, на пример, Бернар из Шартра, француски схоластик прве половине 12. столећа, свестан величине античких филозофа и неоптерећен таштином, живописно објаснио свој став речима: „Ми смо патуљци који су се попели дивовима на рамена. На тај начин видимо више и даље од њих, али не зато што смо оштријег вида или виши растом, него стога што нас они носе на својим раменима и уздижу својом горостасном висином!"13

Кекавмен, писац 11. столећа, саветује сина да школује децу и усмери их ка књигама које носе велику корист, обогаћују знањем и побољшавају умешност, а све то доприноси да човек буде срећан. Његов савременик Михаило Псел, у трактату под називом „О пријатељству“, доноси праву оду наукама и надахнуто истиче да науке спирају прљавштину са душе и њену природу чине чистом и ваздушастом. ${ }^{14}$ На другој страни, византијски људи од пера су умели да се са подсмехом и надменим ниподаштавањем односе према неписмености и да се отворено ругају необразованости. Тако у једном епиграму монахиња Касија, која је живела у 9. веку и била једна од најпаметнијих Византинки, каже следеће:

„Мрзим глупаке када мисле да филозофирају,

Мрзим онога који обучава, а ништа не зна,

Мрзим незнање као Јуду!"

Ваља нагласити да су хришћански аутори у својим делима користили како класичну лексику, тако и стил. Хагиограф Кирил Скитопољски из 6. века у „Житију Евтимија“ изражава жаљење због свог недовољног образовања, пре свега класичног образовања, без којег је, по његовом мишљењу, тешко било шта писати. С друге стране, Василије Велики је препоручивао деци хришћана да уз јеванђеља читају и паганску литературу, на пример Хомера. ${ }^{16}$

Узгред, Хомер је био најчитанији и највише проучавани антички писац у Византији. О његовим бесмртним спевовима су византијски људи од пера помно расправљали и тумачили сваки његов стих, трудећи се да из непресушне ризнице слепог песника позајме стилске фигуре и укључе их у своја књижевна дела. Један педантни савремени истраживач, на пример, израчунао је да византијски писац Никита Хонијат (12/13. век) у свом историјском спису доноси чак 134 цитата из Илијаge (поједине по неколико пута) и 58 цитата из Oguсеје! Следећи на листи „цитираних" код Хонијата био је грчки сатиричар Лукијан из Самосате са (скромних?) 24 цитата. ${ }^{17}$

Византијски ђаци су „наизуст“ учили велике делове Хомерових епова. Франческо Петрарка је почео да учи грчки, између осталог, да би могао да чита Хомера. Учитељ му је био Варлаам, грчки монах из Калабрије у јужној Италији. Међутим, из неког разлога бриљантни лирски песник није много напредовао у савладавању Хомеровог матерњег језика. Саплитао се већ на елементарним знањима. ${ }^{18}$ Ипак, када су му донели рукописе славних спевова, у немогућности да их сам чита, он их је само узбуђено пригрлио. Када се ове чињенице имају у виду, сасвим је јасно зашто енглески економиста и новинар Валтер Багехот (1826-1877) каже: „Човек који није читао Хомера наликује човеку који није видео океан!“

И у позном средњем веку учени Византинци су у потпуности уважавали њихове античке духовне претке. Тако, на пример, Теодор Метохит истиче да су му његове студије омогућиле да

\footnotetext{
13 J. Le Goff, Intelektualci u srednjem vijeku, prijev. N. Grujić (Zagreb: Grafički zavod Hrvatske, 1982), 19.

${ }_{14}$ Кульшиура Визанииии, II, 367.

15 Исто, 369.

${ }_{16}$ Культеура Визанишии, I, 479.

17 ODB, II, 943

18 Р. Радић, Црно сшиолеће. Време Јована V Палеолоїа (1332-1391) (Београд: Завод за уџбенике, 2013), 109
} 
спозна да су велики људи у прошлости све исказали до савршенства тако да нису ништа оставили за нас. Он истиче да свако ко се не диви двојици великана античке филозофије Платону и Аристотелу не изгледа као уман човек. ${ }^{19}$

И у другом делу средњовековног космоса, у латинском свету западне Европе, интелектуалци су се са дужним пијететом односили према наслеђу цивилизација Старог века. Петар од Блоа, мислилац 12. века, поручује: „Из мрака незнања у светлост знања прелази се само тако да се са све ватренијом љубављу читају дела класичних писаца. Нека пси лају, нека свиње грокћу! Нећу због тога бити мање следбеник класика. Њима ћу посветити сву пажњу и зора ће ме сваког дана затећи како их проучавам“. ${ }^{20}$ Француски филозоф 13. столећа Сигер од Брабанта још је одређенији: „Кажем да је Аристотел знања довршио, јер нико од оних који су га следили до данашњих времена, односно кроз готово петнаест стотина година, ништа није његовим написима могао додати, нити у њима пронаћи грешку од неке важности... Аристотел је божанско биће". ${ }^{21}$

\section{Други о Византинцима}

Без обзира на позитиван однос према знању, задобијање образовања у Византијском царству било је повезано са великим тешкоћама и у Царству је било много неписмених. Према неким прорачунима које је својевремено обавио француски византолог Пол Лемерл, у Византији је само 10\% житеља било писмено. ${ }^{22}$ Изнесена процена се мора сматрати прилично апроксимативном и не би се смела апсолутизовати. Преведено на разломке, то би значило да је чак 9/10 Византинаца било неписмено. Упркос том малом постотку, требало би нагласити да су Византинци били „писменији“ и у просеку знатно више образовани од становника западне Европе. Када су крсташи 1204. године заузели Цариград и привремено срушили Византијско царство, с презрењем су говорили о Византинцима као писмењаковићима, а не војницима, ругајући се њиховој навици да са собом носе тршчана пера, мастионице и књиге.

Понекад се у западној Европи на Византинце гледало са нескривеном мржњом, а подесан пример је становиште Франческа Петрарке. У опширном писму из 1352. године, а после закључивања мировног споразума између Ђенове и Византије, велики песник је крајње неповољно писао о Византинцима, наносећи им низ тешких увреда и разних дисквалификација. „А што се тиче лажљивих, кукавичких Грка“ - бележио је Франческо Петрарка - „који се сами ни на шта значајно не одважују, ја их не само не жалим, већ се веома радујем њиховој несрећи и жудим да њихова држава, седиште заблуда, вашим (ђеновљанским) рукама буде оборена“. ${ }^{23}$ Бујица жучних речи пуна големе мржње, непримерене једном поети истанчаних осећања, мора бар донекле да збуни. Иако до крајности лична те стога и натоварена бременом пристрасности, ова се оцена не може сматрати усамљеном на Западу.

Насупрот оценама људи из латинског света западне Европе, Византинци су били уверени у своју интелектуалну надмоћ и, како је то изрекао Димитрије Кидон, један од највећих византијских људи од пера у 14. веку, сматрали су Латине неспособним да се уздигну изнад својих војничких и комерцијалних послова. ${ }^{24}$ Никита Хонијат је записао: „Њихова прекомерна мржња према нама и наше потпуно неслагање с њима нису допуштали никакво осећање пријазности између њих и нас". 25

\footnotetext{
19 В. Татакис, Исйорија визаншиијске философије (Врњачка Бања: Братство Св. Симеона Мироточивог, 1996 ), 254.

20 Le Goff, Intelektualci u srednjem vijeku, 17.

21 Isto, 130-131.

22 P. Lemerle, Élèves et professeurs à Constantinople au Xe siècle (Paris: I'Institut, 1969), 3.

${ }^{23}$ Е. Скржинская, „Петрарка о генуэзцах на Леванте“, Визаншиийский временник 2 (1949): 258-261.

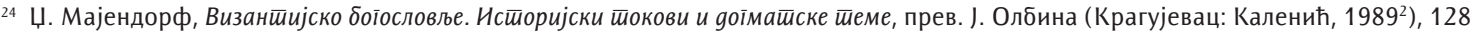

${ }^{25}$ Nicetae Choniatae Historia, I, ed. J. A. Van Dieten (Berolini [Berlin]: Novi Eboraci; De Gruyter, 1975), 568.
} 
Један од најлепших хвалоспева образовању, култури и, уопште, духовним вредностима, захваљујући којима су Византинци били надмоћни у односу на друге народе и које увек односе победу над варварством и дивљом силом, може се прочитати у писаној заоставштини Михаила Хонијата (12/13. век), једног од најпросвећенијих Византинаца. Он је гордо давао предност византијској учености над сировошћу Латина који су у Четвртом крсташком рату, априла 1204. године, заузели Цариград и за неколико деценија срушили Византијско царство. У његовим реченицама се могу препознати и узвишени понос и суспрезана нетрпељивост, као и једна врста немоћног беса који се, узети сви заједно, могу подвести под жал због одсуства библијске правде и мучни утисак због рушења светске империје.

„Опустели су градови у којима су становали хорови муза и у којима је владала Темида и цветала филозофија. Али ми не треба да падамо у очајање и да само јадикујемо. Они који себе сматрају нашим заповедницима разумеју се у словесну уметност као магарац у музику. А ми никада нећемо заборављати на филозофију, нити ћемо престати да се улепшавамо врлинама и образованошћу: биће то право средство које ће нам омогућавати власт над нашим заповедницима, као над дивљим зверима. Пошто су освојили наша утврђења и замкове, они мисле да владају насиљем, отимајући од нас имовину и храну. Но, не може бити трајне и чврсте власти тамо где победници не располажу ни природним, ни стеченим вредностима. Нико не може рећи да лавови, леопарди или вукови владају над људима, макар и кад би ове звери канџама и зубима постигле оно што су остварили наши господари. Ни њима, такође, никада неће успети да нас у потпуности надвладају и победе, па макар присвојили и сва наша добра и макар нас оставили голе и босе, па, чак, и кад би насрнули и на саму плот (тело) нашу. ${ }^{\prime 26}$

\section{Папирус, пергамент, папир}

Одавно је проницљиво запажено да су речи најнепостојаније, али на крају и после свега само оне остају, речи очуване на различитим материјалима као што су камен, папирус, слоновача, порцелан, опека, бронза, пергамент, мермер, стакло, дрво, папир. Када је реч о односу између писаног и усменог, не би их требало посматрати као супротстављене крајности, већ као два комплементарна начина општења међу људима. Усмено није нужно подређено у односу на писмено нити му у сваком случају претходи као примитивнији вид комуникације. ${ }^{27}$

Писана реч је у средњем веку свакако доживела свој врхунац у рукописима, односно рукописним књигама (кодексима). Према сведочанству римског филозофа Сенеке, реч „кодекс“ (codex) означавала је таблице које су се, сједињене, користиле за грубе записе. Као материјал, за њих је у употреби више био пергамент него папирус, а кодекси састављени од пергамента најпре су били збирке докумената. Првобитни кодекс се састојао из једног свежња пресавијених листова. Временом су почели да се склапају из неколико табака који су састављени од четири напола пресавијена листа, односно од шеснаест страна (грчки: иеешраga). ${ }^{28}$

У Византији је књига (biblion, biblos, deltos) одиграла значајну улогу у распростирању Светог писма и његових порука, потом и патристичке литературе, али и за чување наслеђа класичне старине.

Данас у свету постоји око 55.000 грчких рукописа, ${ }^{29}$ од којих је око 40.000 византијских. Они су углавном сачувани у облику кодекса, али, такође, и у виду свитака. Од сачуваних 40.000 византијских рукописа у Грчкој се налази око 16.000 (Света Гора - 11.500, Атина - 2803, а знатан број и на острву Патмосу у гласовитом манастиру Светог Јована Богослова). У Италији

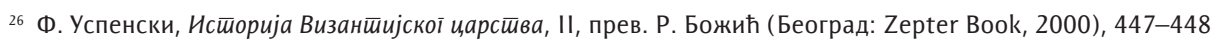

27 Ђ. Бубало, Писана реи у срйском среgњем веку: значај и уйойреба йисаних докуменайа у среgњовековном срйском gрушишву (Београд: Стубови културе, 2009), 280

28 А. П. Каждан, Књиїа и йисаи, у Визанйији, прев. Л. Вилимоновић Орлов (Београд: Еволута, 2018), $35,37$.

29 A. Dain, Les manuscrits, Collection d'Études Anciennes (Paris: Les Belles-Lettres, 1964²), 77. 
је око 8000 рукописа (Ватикан - 4679, Венеција - 1203, Фиренца - 1113, Милано - 1093), у Француској 3117 (Национална библиотека, Париз), манастир Свете Катарине на Синају има 2300, у Русији се налази 2500, у Енглеској 2000, у Јерусалиму 1000, у Румунији 1365, у Аустрији 1047, Шпанији 1000, Немачкој 600 и Холандији 600. У Србији се не налази ниједан рукопис из византијског времена.

Највећи број рукописа су литургијски или богословски и они превладавају у модерним колекцијама и у средњовековним инвентарима манастирских библиотека. Сматра се да је најмање 100.000 рукописа пропало за време и после османлијског освајања Цариграда и рушења Византијског царства у мају 1453. године.

Од 4. века до арабљанске инвазије у 7. столећу, књиге су биле у облику свитака од папируса који је био чешће у употреби од пергамента. Књиге на папирусу су биле у облику свитака (biblion, kylindra, volumen). Израз tomus означавао је ротулус књиге из више делова, а тај је израз и данас остао у употреби. Приликом читања свитак се одвијао десном руком, а завијао левом. На папирусу се писало само с једне стране. ${ }^{30}$ И после губитка Египта (646) није престала употреба папируса, али је он више био допреман у западну Европу, него у Византијско царство. ${ }^{31}$ Ипак, у Византији се он користио за царске повеље још у 9. веку. Листови папируса су били дужи него шири. ${ }^{32}$

Пергамент као материјал на коме се писало поникао је у Малој Азији и задржао старо име pergamenos које упућује на град Пергам, одакле су га достављали у разне делове античког света. Коришћене су коже оваца, телади, јараца, свиња, а за веома луксузне рукописе антилопа и газела. На тлу малоазијског потконтинента пергамент је употребљаван упоредо са папирусом, али га је полако потискивао због тога што су листови овог другог били танки и лако ломљиви. Најстарији рукопис Библије на пергаменту потиче из 6. века и чуван је у манастиру Свете Катарине на Синају, а данас се налази у Британском музеју. Неки од тих рукописа исписани су златним и сребрним словима на пурпуром обојеном пергаменту који красе минијатуре. ${ }^{33}$

Један од најчувенијих докумената у Византији који је настао на пергаменту је Тийик Јована Цимискија или чувени Траі̄oc, назван тако јер је написан на јарећој кожи (грчк. tragos - јарац). По наређењу цара Јована I Цимискија (969-976), духовник Евтимије, монах цариградског манастира Студион, дошао је на Свету Гору и са многобројним игуманима још не сасвим утврђених монашких заједница, између 970. и 972. године, донео први свеопшти типик о уређењу живота на Атосу. Документ, који представља неку врсту монашког „устава“, потписало је 57 духовника и данас се чува у архиву Протата, светогорске управе у Кареји, престоници Свете Горе. Реч је о првом статуту у историји Атона, јединствене „републике“ православних калуђера. ${ }^{34}$

Уз папирус и пергамент, трећи материјал на коме се писало био је папир израђен од памука и папир од конопље или лана. Обе врсте су веома старе, а пронађене су у Кини, одакле су их Арабљани пренели у Европу. Најстарији арапски рукописи на папиру потичу с краја 9. века, али је у Византији папир од памука, чувена бомбицина, ушао у употребу тек два столећа касније. Сматра се да до 13. века није био у општој употреби, али су зато рукописи на памучном папиру од 14. столећа веома бројни. ${ }^{35}$ Премда се у Средоземљу појавио прилично рано, папир је тек после неколико векова потиснуо пергамент. Сматра се да се у Европи то десило у 14. веку. ${ }^{36}$

\footnotetext{
30 L. Breje, Vizantijska civilizacija, prev. I. Nikolajević (Beograd: Nolit, 1976), 300

${ }^{31}$ Каждан, Кюиїа и йисаи у Визанйији, 38.

32 Breje, Vizantijska civilizacija, 300.

33 Isto, 298-299.

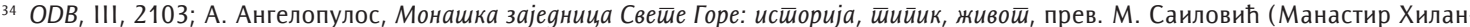
дар, 1997), 64-71.

35 Breje, Vizantijska civilizacija, 299

36 Каждан, Књиїа и йисаи, у Визанйији, 41
} 
У Византији је било веома развијено књиговезачко умеће. Код повезивања рукописних књига (stahoma, amfiasma), кодекс је био заштићен повезима, обично од коже или пергамента, знатно ређе од свиле или племенитих метала. Обично се радило о две кожом прекривене дрвене корице које су заједно држале 24 листа и које је повезивач ушивао. ${ }^{37}$

Рукописи су, дакле, повезивани заједно и коричени у дрвету. За велики формат употребљавана је храстовина украшена кожом и текстилом. Корице јеванђеља и светих књига често су украшаване лепим плочицама од слоноваче или злата са драгим камењем, емајлом, медаљама. Златна плоча из Лувра са сценом посете светих жена Христовом гробу засигурно потиче из таквих корица. ${ }^{38}$

У музеју у Чикагу се чува један јеванђелистар из 13. века који има повез са самог краја византијске епохе. Чине га две букове плоче које су пресвучене смеђом јарећом кожом украшеном концентричним орнаментом са палметама, односно украсима у облику стилизованог палминог лишћа или гранчица, ромбовима и другим мотивима. Име Михаила из Једрена, вероватно књиговесца, забележено је на повезу и уписана је 1466. година. ${ }^{39}$

За историју писања преломан тренутак се догодио око 800. године, када је мајускула, тип грчког и латинског писма који се састоји само од великих слова, ${ }^{40}$ уступио место минускули, која се развила из курзивног писма и задобила облик који има слова неједнаке висине. ${ }^{41}$ Била је то промена која је имала обележја праве револуције упоредиве са штампаном књигом Јохана Гутенберга.

\section{Судбине рукописа}

Стара истина да свака књига има своју судбину, наравно, применљива је и на рукописе, односно рукописне књиге. Међу такве рукописе спада и дело грчког лекара и фармаколога Диоскорида из 1. века. Он је потицао из града Аназарба у малоазијској области Киликији, а радио је и као војни лекар у Риму. Испод његовог пера је изашао драгоцени трактат „Познавање лекова“, састављен на грчком језику, у којем је учењак расправљао о отприлике 600 биљака и готово 1000 лекова. Веома подробан и узорно систематизован, спис је у 6. веку преведен на латински, а уживао је велики углед и у арапском свету. Због својих одлика је током средњег века стекао важно место не само у корпусу оновременог знања медицине, него, ништа мање, и ботанике. У Византији је трактат „Познавање лекова“ словио као основни медицински и фармацеутски приручник и велики број лекара је током векова додавао своје коментаре и понегде усавршавао Диоскоридове рецепте. ${ }^{42}$

Спис "Познавање лекова" сачуван је у најмање десет илустрованих рукописа. Најпознатији је тзв. Беики Диоскориg, рукопис који се чува у Националној библиотеци аустријске престонице (Vienna, Österreichische Nationalbibliothek: Cod. Vindob. med. Gr. 1). Он је препис из 512. године и првобитно је био посвећен принцези Аницији Јулијани, ћерки Аниција Олибрија, потоњег цара Западног Римског царства (472) и Плацидије Млађе, која је највећи део живота провела у Цариграду. Бечки рукопис је најраскошнији византијски научни манускрипт који има 498 минијатура, углавном слике биљака на целој страници, поређане по алфабетском редоследу (насупрот Диоскоридовом првобитном низу). Он такође укључује представе змија, инсеката, паукова, шкорпија, птица и других животиња. На једној од насловних страница приказана су седморица гласовитих античких лекара, а, наравно, није изостала ни страница са ликом Аниције Јулијане којој је рукопис посвећен. ${ }^{43}$

\footnotetext{
37 ODB, I, 305.

38 Breje, Vizantijska civilizacija, 301-302.

39 Isto, 302.

${ }^{40} O D B, I I I, 2141-2142$

${ }^{41}$ ODB, II, 1377-1378; Каждан, Књиїа и йисаи, у Визанйији, 46 сл.

42 Культеура Визанйии, I, 424.

${ }^{43} O D B, 1,632$
} 
Поједине маргиналије показују да је манускрипт Беики Диоскориg био у рукама Латина у времену после 1204. године, али су у 14. и 15. веку монаси цариградског манастира Петра, посвећеног Светом Јовану Продрому (Претечи), додали бројне коментаре. Међу тим духовницима био је Натанаел, лекар у оближњој болници коју је подигао српски краљ Стефан Урош II Милутин. ${ }^{44}$ Он је 1406. године од Јована Хортазмена, византијског писца, учитеља и библиофила, тражио да рукопис рестаурира и преповеже. Хортазмен је делимично преписао унцијални текст и минускулом додао имена личности и називе биљака. Зна се да је 1422/1423. рукопис још увек увек био у Продромовом манастиру, а негде после 1520. године дошао је у руке јеврејског лекара који је лечио султана Сулејмана II Величанственог (1520-1566) и коначно га је купио Карло V, шпански краљ (1516-1556) и цар Светог Римског царства (1519-1558).

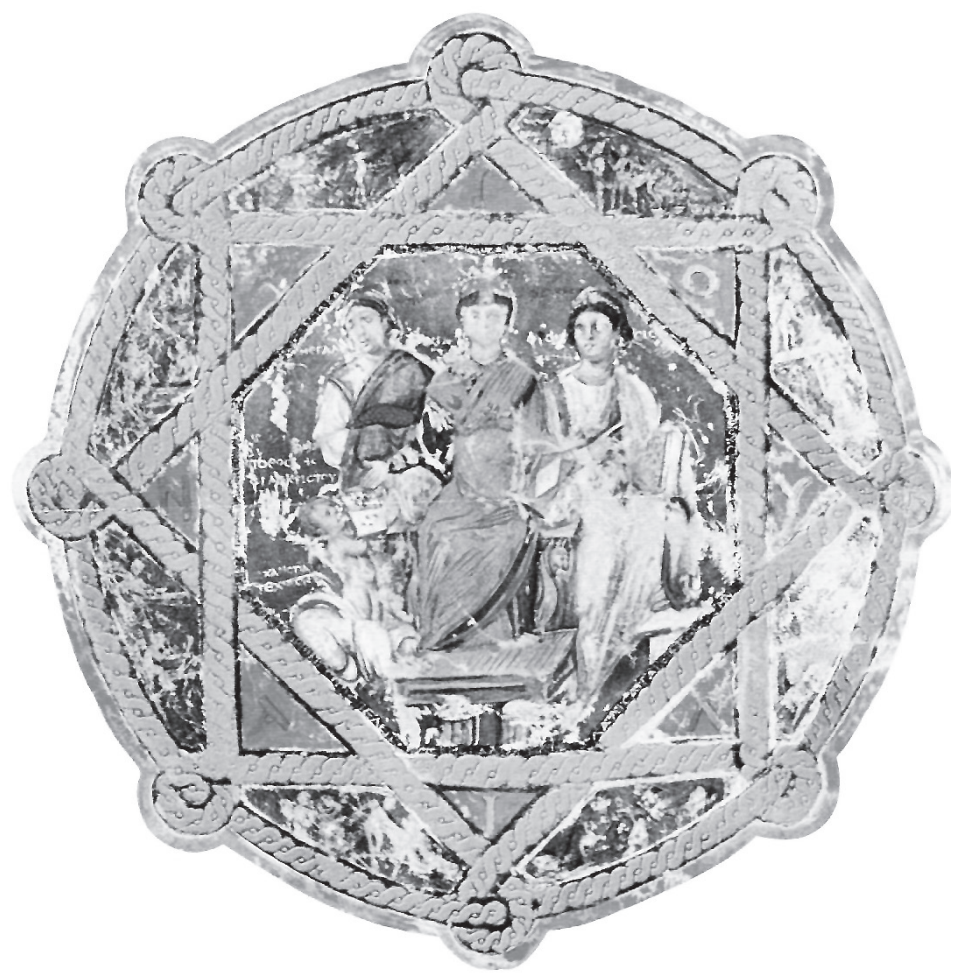

Илустрована посвета принцези Јулијани Аницији 45

Раскошна копија Беикої Дискорияа била је направљена у 10. столећу и данас се налази у Њујорку (New York, Morgan Lib. 652). Некако у исто време, византијски цар Роман II (959-963) једну илустровану верзију овог знаменитог рукописа послао је калифи у Кордобу.

Бечки Диоскориg, најстарији сачувани препис трактата „Познавање лекова“ грчког лекара и фармаколога Диоскорида из 1. века, настао пре више од хиљаду пет стотина година, данас се, дакле, чува и Националној библиотеци у Бечу.

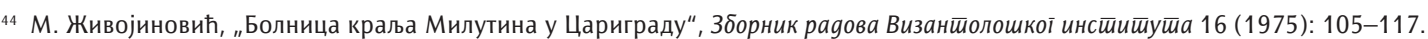

45 Фолио 6, версо, Бечког Диоскорида садржи, у акростиху, похвалу принцези Аницији Јулијани због тога што је дала да се подигне црква у Константинопољу, али и најстарију осликану посвету за коју зна историја илуминирања рукописа. Принцеза седи на престолу (централно), уз бок су јој персонификација великодушности (лево) и персонификација знања (десно), док крај њених ногу клечи још један женски лик, који јој пружа/поклања књигу. - Према: Ingo F. Walther and Norbert Wolf, Codices illustres: The worlds most famous illuminated manuscripts: 400 to 1600 (Köln; London; Los Angeles; Madrid: Taschen, 2001 ), 54.
} 


\section{Калиграфи, скрипторијуми, библиотеке}

Цивилизација рукописа и рукописних књига, састављених на пропадљивом материјалу (папирус, пергамент, папир), подразумевала је и њихово преписивање. Наравно, преписивање је било условљено и потребом да рукописи допру до заинтересованих читалаца. Тако је, на пример, знаменито дело „Познавање природе“ (Naturalis historia) у 37 књига Плинија Старијег (1. век) сачувано у преко 200 средњовековних преписа, од којих је најстарији настао после 8. столећа. ${ }^{46}$ На другој страни, знаменити „Спис о народима“ цара-писца Константина VII Порфирогенита (913-959) сачуван је у само једном рукопису из средњовековне епохе. ${ }^{47}$

Из раздобља средњег века су веома ретки тзв. аутографи, изворни рукописи, односно текстови изашли из пера самих аутора. Критовул са Имброса, византијски историчар 15. века, саставио је историјски спис који обухвата период од 1451. до 1467. године и који је сачуван као аутограф. Кодекс о којем је реч открио је Константин Тишендорф у библиотеци Сараја у Истанбулу 1859. (Istanbul, Codex Seragliensis 6), а читаво дело је први пут издао Карл Милер 1870. године. ${ }^{48}$

Када су у питању антички аутори, наравно, тешко је очекивати да се располаже њиховим аутографима. Међутим, занимљиво је погледати преписе у којима су сачувана њихова разнолика књижевна дела. Тако се у Националној библиотеци у Бечу чувају преписи писама чувеног беседника 4. века, Либанија, за које је утврђено да су изашли из пера Паола Строција (око 1373-1462), истакнутог делатника италијанске ренесансе. У питању је пергаментни кодекс (Phil. gr. 90 1) датован у раздобље Строцијевог живота, односно у шест првих деценија 15. столећа. ${ }^{49}$

У средњем веку вештина лепог писања увек је била на цени. Тако је византијски интелектуалац Јован Евгеник, као врло млад, захваљујући калиграфском рукопису, 1421. године постао патријаршијски нотар. ${ }^{50}$

Уз библиотеке у Византијском царству, световне или манастирске, постојале су преписивачке радионице (скрипторијуми) о којима се зна знатно мање него о онима у западној Европи. ${ }^{51}$ Уз поједине манастире, као што су, на пример, Студион и Одигон у Цариграду и монашки центар Галесиос, северно од Ефеса у Малој Азији, налазили су се скрипторијуми. Став игумана и монаха у манастирским братствима према књизи је у најмању руку био амбивалентан: код неких се може говорити о правом култу књиге, али су други, а нарочито у ранохришћанским столећима, књиге презриво одбацивали. Тако је један игуман критиковао монаха за трошење новца на кодексе уместо да их је употребио за помоћ сиромашнима. ${ }^{22}$ У раздобљу ране Византије (4-7. век) главне преписивачке радионице биле су смештене у средиштима провинција као што су били градови Александрија, Антиохија или Дамаск..53

За разлику од онога што се до 13. века дешавало на Западу, у Византији преписивачи нису били искључиво монаси, него су припадали различитим делатностима: чиновници, нотари, интелектуалци, па у 11. веку чак и један сакупљач пореза. ${ }^{54}$ Међу истакнуте преписиваче мо-

\footnotetext{
${ }^{46}$ Своg gревнейших йисьменых известиий о славянах, том I (I-VI вв.) (Москва, 1991), 18-21.

47 Визаншијски извори за истерију нароgа ууїославије, том II, обрадио Б. Ферјанчић (Београд: Византолошки институт САНУ, 1959, репринт 2007), 4 н. 11

${ }^{48}$ Fragmenta Historicorum Graecorum, V-1, ed. K. Müller (Paris: Firmin Didot, 1870).

${ }^{49}$ Б. Л. Фонкич, Греческие рукойиси евройейских собраний. Палеоїрафические и коgиколоїические исслеgования 1988-1998 і̄̄. (Москва: Архив русской истории, 1999), 128.

${ }_{50}$ С. П. Карпов, Исӣория Трайезундской имӣерии (Санкт-Петербург: Алетейя, 2007), 465.

${ }^{51} D M A$, vol. XI (1988), 119; ODB, III, 1856

$52 O D B, \mathrm{I}, 305$

53 F. Barbije, Istorija knjige, prev. Lj. Mirković (Beograd: Clio, 2009), 61.

54 Breje, Vizantijska civilizacija, 299.
} 
же се убројити и цар Теодосије II (408-450) уз кога је ишао епитет „калиграф“, као и Арета из Кесарије (9/10. век), Димитрије Триклиније (деловао у првој четвртини 14. века), Георгије Хрисокок (прва половина 14. века), Димитрије Ксантопул (прва половина 15. века). ${ }^{55}$ Георгије Амируцис, филозоф, теолог и писац, који је живео у 15. веку, преписивао је нека Аристотелова дела. ${ }^{56}$

Разумљиво, рукописи су се преписивали и у арапском свету. Усама ибн Мункиз, арапски племић, умешни ратник, човек од пера и страсни ловац, који је живео у 12. веку, писац дела Књиїа йоуке, истиче како је његов отац марљиво преписивао Куран и оставио је чак четрдесет три преписа. ${ }^{57}$

3бог оскудице писаћег материјала (пергамент или папир) и времена потребног да се направи копија, књиге су биле ретка и скупа роба. У 9. веку рукопис од око четири стотине фолија коштао је од 15 до 20 номизми (византијски златник), што је било једнако шестомесечној плати чиновника. ${ }^{58}$

У Византијском царству су библиотеке (bibliotheke) биле јавне, царске, патријаршијске, монашке и приватне. ${ }^{59}$ Веома је мало сачуваних података о броју књига у њима. Зна се, рецимо, да је библиотека у манастиру Светог Јована Богослова на острву Патмосу почетком 13. века имала око 330 књига, док је светогорски манастир Велика Лавра Светог Атанасија бројала око 960 рукописа. ${ }^{60}$

Приватне библиотеке су ретко премашивале бројку од 25 томова, али било је и изузетака, па је тако библиотека аристократе Евстатија Воиласа крајем 11. века садржавала 81 књигу. Продавци књига једва да се и помињу. Књиге су се добијале позајмљивањем од пријатеља, наручивањем копирања рукописа у скрипторијумима или коришћењем библиотека. Отуда су биле високо цењене међу свештенством и интелектуалцима. Рукописи из библиотека често су имали клетву против онога ко се усуди да украде књигу.

Будући да због високих цена интелектуалци нису били у могућности да куповином набаве књигу, они су их међусобно размењивали или су их сами преписивали. Тако је Константин Лукит, византијски интелектуалац који је већи део живота провео у Трапезунтском царству, на јужним обалама Црног мора, поседовао велику библиотеку, али је и сам преписивао књиге. Он је, на пример, преписао Хомерову Илијаgу са схолијама, а тај се рукопис сачувао и данас се налази у Амброзијанској библиотеци у Милану. ${ }^{61}$ Лукит је из Цариграда тражио рукопис Oguсеје који тада очигледно није постојао у Трапезунту. ${ }^{62}$ Из његове библиотеке потиче и волуминозни кодекс који садржи седам првих књига Тукидидове Исшорије и дело Дионисија из Халикарнаса $O$ каракӣеру Тукиguga. За ову рукописну књигу основано се верује да ју је Лукит наследио од свог колеге Григорија Хиониадиса. ${ }^{63}$

Било је и учених људи којима књиге такорећи нису биле потребне јер су имали запањујућу меморију. Антоније Велики (3/4. век), родоначелник монашког живота и светитељ, наводно је

\footnotetext{
55 Breje, Vizantijska civilizacija, 300.

${ }^{56}$ Карпов, Исйория Трайезуняской имӣерии, 467.

57 Усама ибн Мункиз, Књиїа йоуке. Сећања арайскої вишеза на бојеве са крсйашима и лавовима, превод, предговор и објашњења Д. Танасковић (Београд: Партенон, 2008²), 61.

58 Byzantine Books and Bookmen (Washington D. C: Dumbarton Oaks 1975), 3, 38

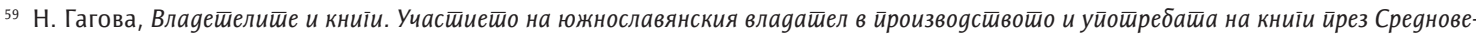

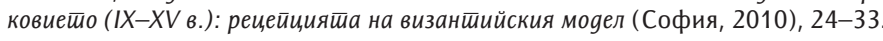

${ }^{60} O D B, I I, 1224$.

${ }^{61}$ C. N. Constantinides, Higher Education in Byzantium in the Thirteenth and Early Fourteenth Centuries (1204 - ca 1310) (Nicosia: Cyprus Research Centre, 1982), 95, 142.

62 Ibid., 95

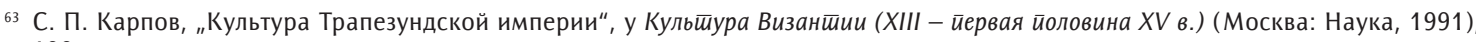
100
} 
у потпуности запамтио свете списе. ${ }^{64}$ Прокл Дијадох (5. столеће), истакнути неоплатоничар, предавач на гласовитој Платоновој академији у Атини, најбољем училишту античког света, знао је напамет, од речи до речи, сва Аристотелова дела из логике. ${ }^{65}$

\section{Селидба рукописа}

Током позновизантијске историје, а посебно у првој половини 14. столећа, у Цариград су се из провинције сливале најбоље научне снаге, па је византијска престоница била збиља духовно жариште и права интелектуална метропола хришћанског Истока. Док су у том времену скоро сви престонички људи од пера били заправо дошљаци из провинција, ${ }^{66}$ дотле је, почевши од друге половине 14. века, а особито током 15. столећа, дошло до супротног процеса. Најумнији људи Царства, ношени снагом сопствене духовне радозналости, али и одређеним негостољубљем Цариграда, хитали су из ромејске престонице не само у провинцију, него и на Запад, чиме је отворен егзодус Византинаца на ову страну. Није без значаја ни чињеница да су на тлу Италије почели да бујају процеси који су наговештавали једну од најблиставијих епоха европске историје, епоху тзв. „хуманизма и ренесансе“. Уопште, друга половина 14. столећа била је раздобље када су комуникације између Истока и Запада, које су подразумевале не само политичке везе, него и разнолика духовна струјања и проток идеја и утицаја, умногоме постале живље, поготово у односу на успорена и дремљива мерила средњовековног света. ${ }^{67}$ Друга половина 14. и прва половина 15. века биле су и време селидбе византијских рукописа на Апенинско полуострво.

На другој страни, италијански интелектуалци, свесни значаја Византије као чувара античког наслеђа, све су више почели да се занимају за тековине старогрчке цивилизације и грчки језик. У тој светлости би требало посматрати и оснивање прве катедре за грчки језик у западној Европи, у Фиренци 1361. године. Та је катедра доживела процват крајем 14. века, када је на њој предавао Манојло Хрисолорас, један од највећих интелектуалаца које је византијска цивилизација дала на свом заласку. Под његовом присмотром стасао је читав круг младих италијанских учењака који су не само овладали грчким језиком, него и водили бригу о грчким рукописима. Међу њима су се издвајали Гварино из Вероне, Ђовани Ауриспа Леонардо Бруни, Роберто Роси, Паоло Строци. Да би у потпуности овладао грчким језиком, Ђовани Ауриспа је 1422/1423. боравио у Византији и између осталог сакупљао рукописе појединих античких аутора и носио их у Италију. Тиме је селидба рукописа из Византије на Апенинско полуострво добила на замаху.

После 1453. године и пропасти Византије уследио је нови егзодус византијских интелектуалаца на Апенинско полуострво. Удаљени од завичаја, далеко од отаџбине које више није било, а суочени са неизвесношћу у новој и умногоме другачијој средини, они су морали да воде рачуна о свакодневним бригама за властиту егзистенцију. Део њих је извор прихода нашао у преписивању грчких рукописа за своје богате италијанске патроне.

Незаобилазна је и улога Висариона, никејског митрополита и потом кардинала, чија је кућа у Риму била стециште Византинаца и италијанских интелектуалаца који су се занимали за грчки језик и грчку античку културу. Он се брижно старао о грчким рукописима, сакупио је велику колекцију и 900 манускрипата је завештао библиотеци Светог Марка у Венецији. ${ }^{68}$ Слична је била и делатност Георгија из Трапезунта у Италији.

\footnotetext{
${ }^{64} O D B, \mathrm{I}, 305$.

${ }_{65}$ Кульшеура Визаншиии, I, 488.

${ }_{66}$ И. Медведев, Визанишийский іуманизм XIV-XVвв. (Ленинград: Алетейя, 1976), 37-38.

67 Радић, Црно сшиолеће. Време Јована V Палеолоїа (1332-1391), 112, 309, 487-489.

${ }^{68} \mathrm{ODB}, \mathrm{I}, 285$.
} 
У Италији је деловао и Јан Ласкарис, угледни Грк и управник библиотеке фирентинског господара Лоренца I Медичија Величанственог (1469-1492), иначе неуморни сакупљач византијских рукописа. ${ }^{69}$ Он је 1491. године обишао Свету Гору и међу осталим манастирима посетио је и монашко братство Хиландара. Познато је да је том приликом пажњу усмерио на фондове Велике Лавре Светог Атанасија и Ватопеда, али је узео и један кодекс из српског манастира и други из Есфигмена. ${ }^{70}$ Разложно је претпоставити да је угледни интелектуалац по свој прилици на Атосу боравио пре августа 1491. године. ${ }^{71}$ Папа Никола V (1447-1455), у кључним годинама пред османлијско запоседање Цариграда, слао је своје људе како би сакупљали грчке рукописе.

Слична делатност вођена је и у Француској, где су се за владавине краља Луја XI (14611483) појавили и учитељи грчког језика. Најпре је то био Георгије Хермоним који је у Паризу предавао и преписивао рукописе и они су касније чинили фонд тамошње Националне библитеке. Извесно време ту је био и Андроник Калист, познат по сакупљању грчких рукописа, који је имао велику збирку, али ју је касније продао у Милану. Нешто касније је француски краљ Франсоа I (1515-1547) ангажовао дванаест зналаца грчког језика и писма који су за његову библиотеку преписивали рукописе. Та библиотека се налазила у Фонтенблоу, а онда је под Шарлом IX (1560-1574) пренета у Париз, где је од ње постала чувена Национална библиотека. Франсоа I је своје људе слао у бивше византијске земље са задатком да сакупљају грчке рукописе. Међу њима се посебно истицао Пјер Жил, који је дуго боравио у Италији и одатле је у Француску донео велики број хирографа.

И у немачким земљама је постојало интересовање за грчке рукописе, па је тако Јован Дерншвам у 16. веку, који је користио везе моћне банкарске куће породице Фугера из Аугсбурга, боравио на Истоку. Тако је, на пример, рукопис светске хронике византијског писца Јована Зонаре (прва половина 12. века) у Цариграду купио за 150 златника од неког Антонија Кантакузина. Пут истока су кретали и емисари владара из куће Хабзбурга, Карла V и његовог брата Фердинанда I (1558-1564), преко којих су настојали да умање опасност од Османлија. Гизелин Бузбек, Фердинандов посланик на Порти, на двору Сулејмана II Величанственог, читавих шест година (1556-1562) боравио је у Цариграду. Његов рад донео је знатне резултате тако да је преко Венеције у Беч допремљено чак 240 рукописа који су ушли у основ грчког рукописног фонда Бечке националне библиотеке. ${ }^{72}$

Селидба грчких рукописа из Византије на Запад била је један од најважнијих путева којима се тамошњи латински свет упознавао са културним наслеђем античке Грчке и Византије. То интелектуално и културно благо чинили су римско право, грчко песништво, филозофија и наука. Трансмисијом рукописа и рукописних књига, дакле, непроцењиве цивилизацијске вредности пренете су у наслеђе европским народима. ${ }^{73}$ По свом значају оне се могу сматрати ванвременским и постале су саставни и неизоставни део цивилизације којој данас припадамо.

\footnotetext{
69 За основне податке о њему в. Г. Л. Курбатов, Нсиооия Визаншии (Нсшориоїрафия) (Ленинград, 1975), 20.

70 G. Speake, "Janus Lascaris' Visit to Mount Athos in 1491", Greek, Roman and Byzantine Studies 34 (1993): 325-330.

71 Р. Радић, „Хиландарска звона су утихнула 1491. године. Прилог историји Свете Горе у XV веку“, у Међунароgни науини скуй

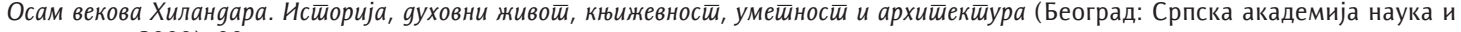
уметности, 2000), 90

72 Katalog der griechischen Handschriften der Österreichischen Nationalbibliothek, Teil 1, Codices historici. Codices philosophici et philologici, von H. Hunger (Wien: Georg Prachner Verlag, 1961), 1-504.

73 Г. Острогорски, Исшиорија Визанйије (Београд: Народна књига-Алфа, 1998³), 529-530.
} 


\section{Литература:}

1. Angelopulos, Atanasije. Monaška zajednica Svete Gore: istorija, tipik, život. Prev. M. Sailović. Manastir Hilandar, 1997.

2. Barbije, Frederik. Istorija knjige. Prev. Lj. Mirković. Beograd: Clio, 2009.

3. Brauning, Robert. Srednjovekovni i savremeni grčki jezik. Prev. J. Petrović. Dopuna bibligrafije D. Aničić. Loznica: Karpos, 2005.

4. Breje, Luj. Vizantijska civilizacija. Prev. I. Nikolajević. Beograd: Nolit, 1976.

5. Bubalo, Đorđe. Pisana reč u srpskom srednjem veku: značaj i upotreba pisanih dokumenata u srednjovekovnom srpskom društvu. Beograd: Stubovi kulture, 2009.

6. Byzantine Books and Bookmen. Washington D. C: Dumbarton Oaks 1975.

7. Constantinides, C. N. Higher Education in Byzantium in the Thirteenth and Early Fourteenth Centuries (1204 - ca 1310). Nicosia: Cyprus Research Centre, 1982.

8. Dain, A. Les manuscrits, Collection d'Études Anciennes. Paris: Les Belles-Lettres, 19642.

9. Dictionary of the Middle Ages, vol. X. Ed. J. R. Strayer. New York: Scribner, 1988.

10. Dictionary of the Middle Ages, vol. XII. Ed. J. R. Strayer. New York: Scribner ,1989.

11. Enciklopedija pravoslavlja, II. Beograd: Savremena administracija, 2002.

12. Fragmenta Historicorum Graecorum, V-1. Ed. K. Müller. Paris: Firmin Didot, 1870.

13. Фонкич, Б. Л. Греческие рукойиси евройейских собраний. Палеоїрафические и коgиколоїические исслеgования 1988-1998 ї. Москва: Архив русской истории, 1999.

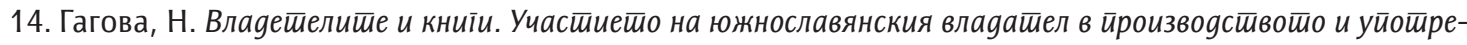

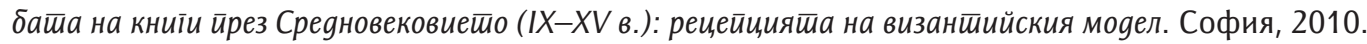

15. Ibn Munkiz, Usama. Knjiga pouke. Sećanja arapskog viteza na bojeve sa krstašima i lavovima. Prevod, predgovor i objašnjenja D. Tanasković. Beograd: Partenon, $2008^{2}$.

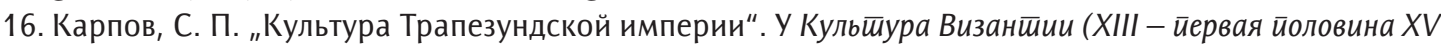
в.). Москва: Наука, 1991.

17. Карпов, С. П. Нсииория Трайезуняской имиеерии. Санкт-Петербург: Алетейя, 2007.

18. Katalog der griechischen Handschriften der Österreichischen Nationalbibliothek, Teil 1, Codices historici. Codices philosophici et philologici. Von H. Hunger. Wien: Georg Prachner Verlag, 1961.

19. Každan, Aleksandar P. Knjiga i pisac u Vizantiji. Prev. L. Vilimonović Orlov. Beograd: Evoluta, 2018.

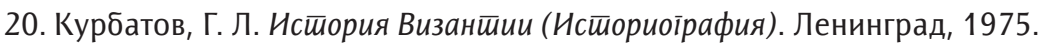

21. Le Goff, Jacques. Intelektualci u srednjem vijeku. Prijev. N. Grujić. Zagreb: Grafički zavod Hrvatske, 1982.

22. Lemerle, Paul. Élèves et professeurs à Constantinople au Xe siècle. Paris: I'Institut, 1969.

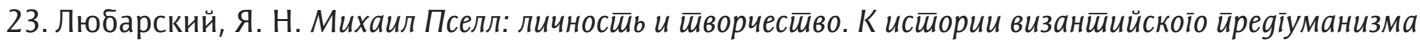
Москва: Наука, 1978.

24. Majendorf, Dž. Vizantijsko bogoslovlje. Istorijski tokovi i dogmatske teme. Prev. J. Olbina. Kragujevac: Kalenić, $1989^{2}$

25. Медведев, И. П. Визанииийский іуманизм XIV-XVвв. Ленинград: Алетейя, 1976.

26. Nicetae Choniatae Historia, I. Ed. J. A. Van Dieten. Berolini [Berlin]: Novi Eboraci; De Gruyter, 1975.

27. Oksfordska istorija Vizantije. Prir. S. Mango. Prev. M. Miloradović, P. J. Marković. Beograd: Dereta, 2004.

28. Ostrogorski, Georgije. Istorija Vizantije. Beograd: Narodna knjiga-Alfa, $1998^{3}$.

29. Radić, Radivoj. Crno stoleće. Vreme Jovana V Paleologa (1332-1391). Beograd: Zavod za udžbenike, 2013.

30. Radić, Radivoj. „Hilandarska zvona su utihnula 1491. godine. Prilog istoriji Svete Gore u XV veku“. U Međunarodni naučni skup Osam vekova Hilandara. Istorija, duhovni život, književnost, umetnost i arhitektura, 85-92. Beograd: Srpska akademija nauka i umetnosti, 2000.

31. Radić, Radivoj. Vizantija i Srbija: plamen i odsjaji. Beograd: Stubovi kulture, 2010.

32. Самодурова, 3. Г. Культиура Визанйии (IV - иеервая йоловина VII в.), I. Москва: Наука, 1984.

33. Самодурова, 3. Г. Культиура Визанйии (вйорая йоловина VII-XII в.), II. Москва: Наука, 1989.

34. Своg gревнейших йисьменьхх извесииий о славянах, том I (I-VI вв.). Москва, 1991. 
Радић Р. „Византинци и писана реч“, 2-16

35. Скржинская, Е. „Петрарка о генуэзцах на Леванте“, Визанииийский временник 2 (1949): 245-266.

36. Speake, Graham. "Janus Lascaris' Visit to Mount Athos in 1491". Greek, Roman and Byzantine Studies 34 (1993): 325-330.

37. Tatakis, Vasilij. Istorija vizantijske filosofije. Vrnjačka Banja: Bratstvo Sv. Simeona Mirotočivog, 1996.

38. The Oxford Dictionary of Byzantium, II. Ed. A. P. Kazhdan. New York; Oxford, 1991.

39. Uspenski, Fjodor. Istorija Vizantijskog carstva, II. Prev. R. Božić. Beograd: Zepter Book, 2000.

40. Vizantijski izvori za istoriju naroda Jugoslavije, tom II. Obradio B. Ferjančić. Beograd: Vizantološki institut SANU, 1959, reprint 2007.

41. Vizantijski izvori za istoriju naroda Jugoslavije, VI. Beograd: Vizantološki institut SANU, 1986.

42. Walther, Ingo F. and Norbert Wolf. Codices illustres: The worlds most famous illuminated manuscripts: 400

to 1600. Köln; London; Los Angeles; Madrid: Taschen, 2001.

43. Živojinović, Mirjana. „Bolnica kralja Milutina u Carigradu“. Zbornik radova Vizantološkog instituta 16 (1975): 105-117.

\title{
Byzantines and the Written Word
}

\begin{abstract}
Summary
Byzantine civilization did not know the printed book: it was a civilization of manuscripts and manuscript books (codices) made of papyrus, parchment, and paper. The ancient Greeks bequeathed to the Byzantines the word Logos (in multiple meanings - word, speech, mind, reason, supreme principle, the divine creative power, the word of God, the word as the bearer of life and light), as the greatest treasure. The Rhomaioi (Byzantines) polished the skill of use of words and the ability to persuade with words to their full glory. However, the use of words within Byzantine civilization flourished completely and reached its apogee in literature. An important feature of the Greek language in Byzantine times (the period from the fourth to the fifteenth century) is diglossia, i.e. the existence of two different varieties of a language used under different conditions within a community - a high, socially prestigious form, used for writing, and a low, simpler, everyday spoken form. For Christians, a sensitive issue was the attitude towards the ancient pagan heritage: they accepted what did not conflict with their dogmas, and rejected the rest.

Today, there are about 55,000 Greek manuscripts in the world, of which about 40,000 are Byzantine. In order to be distributed to readers and preserved from decay, manuscript books were being transcribed in scriptoriums, in which not only monks but also secular people of various professions were working. Books were very expensive. There were public, imperial, patriarchal, monastic, and private libraries, with not large collections of manuscripts. As Byzantine civilization was approaching its decline, the migration of Greek manuscripts from Byzantium to the Latin world of Western Europe began. In that way, the great heritage of ancient civilization was preserved and transferred to European countries.
\end{abstract}

Keywords: Byzantium, manuscripts, codices, scriptoriums, words, civilization, antiquity, Western Europe

Примљено: 5. фебруара 2021 Нсправке рукописа: 11. марта 2021. Прихваћено за објављивање: 15. марта 2021 